\title{
A study on water quality assesment and its treatment over cnsl resin
}

\author{
S. Muthukumar ${ }^{1 *}$, P. Manivannan ${ }^{1}$, S. Kalyanasundharam ${ }^{2}$, \\ K. Santhanalakshmi ${ }^{1}$, P. Jacquline Rosy ${ }^{1}$ \\ ${ }^{1}$ Department of Chemistry, IFET college of Engineering, Villupuram, Pincode - 605 108. Tamilnadu \\ ${ }^{2}$ Department of chemistry, Poompuhar College (Autonomous), Melaiyur, India - 609107 \\ *E-mail address: muthukumarscientist@gmail.com
}

\begin{abstract}
A study on water quality assessment and its treatment over CNSL resin has been planned. Water samples from various sources like bore well, ground water, municipal water, stagnated water and rain water were collected from seven locations in and around Marudhur of Villupuram. These seven samples were analyzed for various parameters such as TDS, pH, total hardness, Calcium hardness, Magnesium hardness, Iron, nitrate, chloride, sulphate and alkalinity in a well-equipped laboratory as per standard methods. After analyzing the seven samples the results revealed the nature of samples. i.e., whether they are scale forming or corrosive or neutral water which was found using Langlier and Rayznar indexes. Even the probable combination method was employed to check the correctness of determination of various parameters and found to be correct. Out of seven samples four samples (sample 1, 2, 3 and 5) where found to have more hardness they were taken for analysis with CNSL resin. The CNSL resin was prepared in the laboratory and the samples agitated with the CNSL resin. Analysed the samples and found the hardness were reduced. The results show that the percentage of removal of cation increases when adsorbent dose increases.
\end{abstract}

Keywords: water; quality; treatment

\section{INTRODUCTION}

The law of conservation of mass which was first stated by Lomonossaff (1756) and later formulated and established by Lavoisier (1774). "The total mass of a substance taking part in a reaction remains the same throughout the change". The law of conservation of energy can alternatively be termed as law of conservation of water which might be like "Water can neither be created nor destroyed". Of this global water potential, about $97.2 \%$ have been distributed in the ocean as salty water, and $2.8 \%$ as fresh water. At any time the whole world depends on this small fraction of water to meet its demands. Out of this fresh water of $2.8 \%$ about $2.2 \%$ is found to be as surface water and the balance $0.6 \%$ appears as ground water even out of this $2.2 \%$ of surface water $2.15 \%$ is in the form of glaciers and ice caps and only of the order of $0.01 \%$. The remaining quantity is preserved as water vapour in atmosphere $(0.001 \%)$ and soil moisture $(0.002 \%)$ in the top soil up to $0.6 \mathrm{~m}[1]$. 


\section{METHEODOLOGY AND EXPERIMENTAL PROCEDURE}

\section{A Water sample collection}

Water samples from bore well, ground water, municipal water, stagnated water were collected from several locations in and around Maruthur of Villupuram town of Villupuram district, Tamilnadu. New polythene bottles treated with dilute Hydrochloric acid and then repeatedly washed with water and finally with distilled water. Some of them were cleaned with detergents since dilute hydrochloric acid was not much effective. All the samples collected are of the type called instantaneous, spot, snap or grab samples type i.e., manually collected single portion of sample of water. Thus the samples from seven locations collected in seven polythene bottles and transported to the laboratory for analyzing the physiochemical characteristics within 24 hours of collection.

\section{B Procedure for analysis}

The total dissolved solids (TDS) is measured by a method called electrical conductivity measurement is followed. electrical conductivity of water is directly proportional to its dissolved mineral matter content. the unit of conductivity is micromho/cm. since conductivity varies with the temperature the result is usually reported at $25^{\circ} \mathrm{C}$. Thus measurement of conductivity provides a very rapid measure of obtaining good approximate knowledge of total dissolved solids concentration and salinity of samples.

The $\mathrm{pH}$ of the water sample was determined by using direct reading $\mathrm{pH}$ meter. The $\mathrm{pH}$ meter can be used for sample analysis after calibrating with buffer solutions at room temperature. Electrodes dipped i to the samples still steady values are read in the meter. The total hardness of the sample was estimated by complexometric titration method using EDTA solution and eriochrome black - $\mathrm{T}$ indicator. From the titer value the total hardness of the given water sample can be determined. Calcium hardness alone can be calculated by titrating the water sample with EDTA after adding $1 \mathrm{ml} 6 \mathrm{~N} \mathrm{NaOH}$ and pinch of muroxide indicator. From the value of calcium and total hardness the magnesium hardness can be calculated. Iron was estimated by phenanthroline method. The complexing agent 1,10 - phenanthroline is specific to ferrous iron and its $\mathrm{pH}$ dependent. Initially iron is brought in to solution by acidification and then all the iron is reduced to ferrous state by boiling with hydroxylamine. Ferrous iron produced reacts with phenanthroline at $\mathrm{pH}$ between 2.9 and 3.5 to form an orange red complex having absorption maximum at $510 \mathrm{~nm}$. a spectrophotometer was used to record absorbance at $510 \mathrm{~nm}$ and iron concentration was read from the standard calibration graph. Among the methods available for the determination of nitrate, brucine method is rapid, simple and precise and hence followed here. Nitrate react with brucine in strong sulphuric an acid solution to form a yellow color which is measured photo metrically. Chlorides measured by titrating the water sample with standard silver nitrate solution using potassium chromate as indicator. Sulphate in water can be estimated by treating the water sample with barium chloride and the turbid suspension of Barium sulphate formed. The concentration of the suspension can be measured with turbidimeter. Alkalinity is the quantitative capacity of aqueous media to react with hydrogen ions. The alkalinity of natural or treated waters is normally due to the presence of bicarbonates, carbonate and hydroxide compounds of calcium, magnesium, sodium and potassium. Borates and phosphates and silicates also contribute of alkalinity. Alkalinities are calculated by titrating the water samples with a standard acid using phenolphthalein and methyl orange indicators 


\section{Cashew nut shell liquid}

Cashew nut shell liquid in short CNSL is a soft honey comb structure containing dark reddish brown viscous liquid. It is a byproduct of the cashew industry which is the pericarp fluid of the nut. It is considered to be better as well as cheaper material and can be utilized as a adsorbent, when treated with formaldehyde and con sulphuric acid. The industrial applications of the shell oil are based upon its polymerisation to a rubber like material under the influence of acids and on the formation of a wide range of condensation products with aldehydes. The later are generally hard, infusible and extremely resistant to the action of chemicals such as acids and alkalis. The different water samples are agitated with different concentration of CNSL resin and plotted against various time intervals and plotted a graph to study the effectiveness of adsorption of cations there by it can be used as Ion exchange resin.

\section{RESULTS AND CALCULATIONS}

Table 1. Findings and calculations.

\begin{tabular}{|c|c|c|c|c|c|c|c|}
\hline Parameter & S 1 & S 2 & S 3 & S 4 & S 5 & S 6 & S 7 \\
\hline TDS & 2500 & 3100 & 3150 & 376 & 1200 & 350 & 320 \\
\hline pH & 8.2 & 7.9 & 8.3 & 7.1 & 7.8 & 7.3 & 7.1 \\
\hline Tot. hardness & 1775 & 1662 & 2211 & 264 & 842 & 188 & 224 \\
\hline Ca hardness & 1437 & 996 & 1810 & 216 & 689 & 112 & 183 \\
\hline Mg hardness & 319 & 666 & 402 & 48 & 153 & 76 & 41 \\
\hline Iron & 0.2 & 0.2 & 0.2 & 0.1 & 0.1 & 0.1 & 0.1 \\
\hline Nitrate & 18.9 & 155 & 23.9 & 2.9 & 9 & 3.3 & 2.5 \\
\hline Chloride & 187 & 723 & 236 & 28.1 & 89.7 & 81.5 & 24 \\
\hline Sulphate & 154.1 & 116 & 194 & 23.1 & 74 & 13 & 20 \\
\hline Alkalinity & 1874 & 817 & 2361 & 282 & 899 & 92.1 & 239 \\
\hline
\end{tabular}

Sample 1 on chemical analysis and probable combination calculation show that it contains calcium and magnesium as their respective carbonates to the extent of $1705 \mathrm{ppm}$. Therefore it should be a scale forming nature of water which was confirmed by

W Q I values. Langlier and Rayznar index show that it is scale forming water.

Sample 2 on chemical analysis and probable combination calculation show that it contains calcium and magnesium as their respective carbonates to the extent of $996 \mathrm{ppm}$. Its sulphates and chlorides are around $1200 \mathrm{ppm}$. Therefore it should be a scale forming nature of water which was confirmed by W Q I values. Langlier and Rayznar index show that it is scale forming water. Sample 3 on chemical analysis and probable combination calculation show that it contains calcium and magnesium as their respective carbonates to the extent of 2150 ppm. Therefore it should be a scale forming nature of water which was confirmed by

W Q I values. Langlier and Rayznar index show that it is scale forming water.

Sample 4 on chemical analysis and probable combination calculation show that it contains calcium and magnesium as their respective carbonates to the extent of 256 $\mathrm{ppm}$. Therefore it should be neither scale forming nor a corrosive which was confirmed by W Q I values. Langlier and Rayznar index show that it is neither scale forming nor corrosive. 
Sample 5 on chemical analysis and probable combination calculation show that it contains calcium and magnesium as their respective carbonates to the extent of $818 \mathrm{ppm}$. Therefore it should be a scale forming nature of water which was confirmed by W Q I values. Langlier and Rayznar index show that it is scale forming water.

Sample 6 on chemical analysis and probable combination calculation show that it contains calcium and magnesium as their respective carbonates to the extent of $197 \mathrm{ppm}$. Therefore it should be a corrosive nature of water which was confirmed by W Q I values, Langlier and Rayznar index.

Sample 7 on chemical analysis and probable combination calculation show that it contains calcium and magnesium as their respective carbonates to the extent of $213 \mathrm{ppm}$. Therefore it should be neither scale forming nor a corrosive and confirmed by W Q I, Langlier and Rayznar index.

Table 2. Data for rapid calculation of langelier index.

\begin{tabular}{|c|c|c|c|c|c|c|c|c|c|c|c|c|c|c|c|}
\hline \multicolumn{3}{|c|}{$\mathbf{A}$} & & \multicolumn{3}{|c|}{ B } & \multicolumn{4}{|c|}{ C } & \multicolumn{4}{|c|}{ D } & \multirow[b]{2}{*}{ D } \\
\hline \multicolumn{3}{|c|}{$\begin{array}{c}\text { Total solids } \\
\text { mg/l }\end{array}$} & \multirow{2}{*}{$\begin{array}{c}\mathbf{A} \\
0.1 \\
\end{array}$} & \multicolumn{3}{|c|}{ Temperature ${ }^{0} \mathrm{C}$} & \multirow{2}{*}{$\begin{array}{c}\text { B } \\
2.6\end{array}$} & \multicolumn{3}{|c|}{$\begin{array}{l}\text { Calcium hardness } \\
\mathrm{As} \mathrm{CaCO}_{3} \mathrm{mg} / \mathrm{l}\end{array}$} & \multirow{2}{*}{$\begin{array}{l}\mathbf{C} \\
0.6\end{array}$} & \multicolumn{3}{|c|}{$\begin{array}{l}\text { Methyl orange } \\
\text { alkalinity } \\
\text { As } \mathrm{CaCO}_{3} \mathrm{mg} / \mathrm{l}\end{array}$} & \\
\hline 50 & To & 300 & & 0 & to & 1.1 & & 10 & To & 11 & & 10 & to & 11 & 1.0 \\
\hline 400 & To & 1000 & 0.2 & 2.2 & to & 5.5 & 2.5 & 12 & To & 13 & 0.7 & 12 & to & 13 & 1.1 \\
\hline & & & & 6.7 & to & 8.9 & 2.4 & 14 & To & 7 & 0.8 & 14 & to & 17 & 1.2 \\
\hline & & & & 10.0 & to & 13.3 & 2.3 & 18 & To & 22 & 0.9 & 18 & to & 22 & 1.3 \\
\hline & & & & 14.4 & to & 16.7 & 2.2 & 23 & To & 27 & 1.0 & 23 & to & 27 & 1.4 \\
\hline & & & & 17.8 & to & 21.1 & 2.1 & 28 & To & 34 & 1.1 & 28 & to & 35 & 1.5 \\
\hline & & & & 22.2 & To & 26.7 & 2.0 & 35 & To & 43 & 1.2 & 36 & to & 44 & 1.6 \\
\hline & & & & 27.8 & To & 31.1 & 1.9 & 44 & To & 55 & 1.3 & 45 & to & 55 & 1.7 \\
\hline & & & & 32.2 & To & 36.7 & 1.8 & 56 & To & 69 & 1.4 & 56 & to & 69 & 1.8 \\
\hline & & & & 37.8 & To & 43.3 & 1.7 & 70 & To & 87 & 1.5 & 70 & to & 88 & 1.9 \\
\hline & & & & 44.4 & To & 50.0 & 1.6 & 88 & To & 110 & 1.6 & 89 & to & 110 & 2.0 \\
\hline & & & & 51.1 & To & 55.6 & 1.5 & 111 & To & 138 & 1.7 & 111 & to & 139 & 2.1 \\
\hline & & & & $\begin{array}{l}56.7 \\
\end{array}$ & To & 63.3 & 1.4 & 139 & To & 174 & 1.8 & 140 & to & 176 & 2.2 \\
\hline & & & & 64.4 & To & 71.1 & 1.3 & 175 & To & 220 & $\begin{array}{l}1.9 \\
\end{array}$ & 177 & to & 220 & 2.3 \\
\hline & & & & 72.2 & To & 81.1 & 1.2 & 230 & To & 270 & 2.0 & 230 & to & 270 & 2.4 \\
\hline & & & & & & & & 280 & To & 340 & 2.1 & 280 & to & 350 & 2.5 \\
\hline & & & & & & & & 350 & To & 430 & 2.2 & 360 & to & 440 & 2.6 \\
\hline & & & & & & & & 440 & To & 550 & 2.3 & 450 & to & 550 & 2.7 \\
\hline & & & & & & & & 560 & To & 690 & 2.4 & 560 & to & 690 & 2.8 \\
\hline & & & & & & & & 700 & To & 870 & 2.5 & 700 & to & 880 & 2.9 \\
\hline & & & & & & & & 880 & To & 1000 & 2.6 & 890 & to & 1000 & 3.0 \\
\hline
\end{tabular}


Table 3. Probable combination and water quality index.

\begin{tabular}{|c|c|c|c|c|c|c|c|c|c|c|c|c|c|c|}
\hline 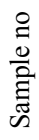 & $\mathrm{CaCO}_{3}$ & $\mathrm{CaCl}_{2}$ & $\mathrm{CaSO}_{4}$ & $\mathrm{MgCO}_{3}$ & $\mathrm{MgCl}_{2}$ & $\mathrm{Na}_{2} \mathrm{CO}_{3}$ & $\mathrm{Na}_{2} \mathrm{SO}_{4}$ & $\mathrm{NaCl}$ & $\mathrm{NaNO}_{3}$ & $\mathrm{SiO}_{2}$ & $\mathrm{I}_{\text {sat }}$ & $I_{\text {sta }}$ & $\begin{array}{r}\text { TDS } \\
\text { cal }\end{array}$ & $\begin{array}{c}\text { TDS } \\
\text { exp }\end{array}$ \\
\hline 1 & 1437 & ----- & ---- & 267.96 & ---- & 126.14 & 227.93 & 308.3 & 25.90 & ---- & +2.4 & 3.4 & 2393 & 2500 \\
\hline 2 & 996 & 64.48 & 164.33 & ----- & 1114.0 & ----- & ----- & 345.5 & 212.49 & 100 & +2.0 & 3.9 & 2997 & 3100 \\
\hline 3 & 1810 & ---- & ----- & 337.68 & ---- & 159.00 & 286.96 & 389.1 & 32.77 & 100 & +2.5 & 3.3 & 3116 & 3150 \\
\hline 4 & 216 & ----- & ----- & 40.32 & ---- & 19.08 & 34.17 & 46.33 & 3.98 & ----- & +0.2 & 6.7 & 360 & 376 \\
\hline 5 & 689 & ----- & ----- & 128.52 & ---- & 60.42 & 109.46 & 147.9 & 12.33 & ----- & +1.8 & 4.2 & 1148 & 1200 \\
\hline 6 & 112 & 7.05 & 18.42 & ---- & 127.19 & ---- & ---- & 38.09 & 4.52 & ----- & -0.3 & 7.9 & 307 & 350 \\
\hline 7 & 183 & ---- & ----- & 34.44 & ---- & 15.90 & 29.58 & 39.57 & 3.42 & ----- & +0.1 & 6.9 & 306 & 320 \\
\hline
\end{tabular}

Water quality index [4] uses $\mathrm{pH}$ in conjunction with total salinity, temperature, calcium - content and total alkainity is used to determine whether a water is corrosive in nature or having scale forming tendencies. Langlier - saturation index and Ryznar stability index based on the actual $\mathrm{pH}$ values and theoritical $\mathrm{pH}$ values are the widely employed parameters to measure the particular water to be corrosive or to form scale.

$$
\mathrm{pH}_{\mathrm{s}}=(9.3+\mathrm{A}+\mathrm{B})-(\mathrm{C}+\mathrm{D})
$$

Where $\mathrm{A}$ is the factor for total solids, $\mathrm{B}$ is the factor for temperature, $\mathrm{C}$ is the factor for calcium hardness and $\mathrm{D}$ is the factor for total alkalinity.

Values of A, B, C, and D from the table and calculate $\mathrm{pHs}$ and find out the Langelier saturation Index $\left(\mathrm{I}_{\text {sat }}\right)$ and Ryznar stability index $\left(\mathrm{I}_{\text {stab }}\right)$. If $\mathrm{I}_{\text {sat }}$ is zero, the water is in chemicl balance; if it is a plus quantity, scale forming tendencies are indicated; if it is a negative quantity corrosive tendencies are indicated. Water with Ryznar stability index 6 to 7 neither scale forming nor corrosive. Water with stability index below 6 will be scale forming and above 7 will be corrosive.

$$
\begin{aligned}
& \text { Langelier saturation Index, } \mathrm{I}_{\mathrm{sat}}=\mathrm{pH}-\mathrm{pH}_{\mathrm{s}} \\
& \text { Ryznar saturation Index, } \mathrm{I}_{\text {stab }}=2 \mathrm{pH}_{\mathrm{s}}-\mathrm{pH}
\end{aligned}
$$

Where $\mathrm{pH}$ is the actual $\mathrm{pH}$ observed and $\mathrm{pH}_{\mathrm{s}}$ is the theoretical $\mathrm{pH}$ value calculated as follows: 


\section{Sample 1 - bore well water - Kanniyamman kovil}

Total solids

Temperature

$$
=\mathrm{A} \quad=2500
$$

Calcium hardness

$=\mathrm{B}=30^{\circ} \mathrm{C}$

Alkalinity

$$
\begin{aligned}
& =\mathrm{C}=1437 \\
& =\mathrm{D}=1874
\end{aligned}
$$

$$
\mathrm{pH} \quad=8.2
$$

$$
\mathrm{pH}_{\mathrm{s}} \quad=(9.3+\mathrm{A}+\mathrm{B})-(\mathrm{C}+\mathrm{D})
$$$$
=(9.3+0.2+1.9)-(2.6+3.0)
$$

$$
\begin{aligned}
& =11.4-5.6 \\
& =5.8
\end{aligned}
$$

Langelier saturation index $=5.8$

$$
\begin{array}{r}
\mathrm{I}_{\mathrm{sat}}=\mathrm{pH}-\mathrm{pH}_{\mathrm{s}} \\
=8.2-5.8 \\
=+2.4
\end{array}
$$

Since it is a plus quantity it indicates the scale forming tendencies of water. Ryznar stability index

$$
\begin{array}{cc} 
& =2 \mathrm{pH}_{\mathrm{s}}-\mathrm{pH} \\
\mathrm{I}_{\text {stab }} & 5.8 \times 2-8.2 \\
= & 11.6-8.2=3.4
\end{array}
$$

Since the value is below 6.0 the water will have the tendency to deposit scale.

\section{Sample 2 - bore well water - M.R.K street}

Total solids

Temperature

Calcium hardness

Alkalinity

$$
\begin{aligned}
\mathrm{pH} \quad & =7.9 \\
& \mathrm{pH}_{\mathrm{s}}=(9.3+\mathrm{A}+\mathrm{B})-(\mathrm{C}+\mathrm{D}) \\
= & (9.3+0.2+1.9)-(2.6+2.9) \\
& =11.4-5.5 \\
& =5.9 \\
& =\mathrm{pH}-\mathrm{pH}_{\mathrm{s}} \\
\mathrm{I}_{\mathrm{sat}} & =7.9-5.9 \\
& =+2.0
\end{aligned}
$$$$
\mathrm{pH}_{\mathrm{s}}=(9.3+\mathrm{A}+\mathrm{B})-(\mathrm{C}+\mathrm{D})
$$

Since it is a plus quantity it indicates the scale forming tendencies of water. Ryznar stability index

$$
\begin{aligned}
\mathrm{I}_{\mathrm{stab}} \quad= & 2 \mathrm{pH}_{\mathrm{s}}-\mathrm{pH} \\
& =5.9 \times 2-7.9 \\
& =11.8-7.9 \\
& =3.9
\end{aligned}
$$

Since the value is below 6.0 the water will have the tendency to deposit scale.

Sample 3 - well water - Dharmaraja street

Total solids

Temperature

Calcium hardness

Alkalinity

$$
\begin{aligned}
=\mathrm{A} & =3150 \\
=\mathrm{B} & =30^{\circ} \mathrm{C} \\
& =\mathrm{C}=1810 \\
=\mathrm{D} & =2361
\end{aligned}
$$$$
\mathrm{pH} \quad=8.3
$$ 


$$
\begin{aligned}
\mathrm{pH}_{\mathrm{s}} \quad & =(9.3+\mathrm{A}+\mathrm{B})-(\mathrm{C}+\mathrm{D}) \\
& =(9.3+0.2+1.9)-(2.6+3.0) \\
& =11.4-5.6 \\
& =5.8 \\
& =\mathrm{pH}-\mathrm{pH}_{\mathrm{s}} \\
& =8.3-5.8 \\
& =+2.5
\end{aligned}
$$

Since it is a plus quantity it indicates the scale forming tendencies of water. Ryznar stability index

$$
\begin{aligned}
\mathrm{I}_{\text {stab }} \quad & =2 \mathrm{pH}_{\mathrm{s}}-\mathrm{pH} \\
& =5.8 \times 2-8.2 \\
& =11.6-8.3 \\
& =3.3
\end{aligned}
$$

Since the value is below 6.0 the water will have the tendency to deposit scale.

$$
\begin{aligned}
& \text { Sample } 4 \text { - bore well - Anna nagar } \\
& \text { Total solids }=\mathrm{A}=376 \\
& \text { Temperature }=\mathrm{B}=30^{\circ} \mathrm{C} \\
& \text { Calcium hardness } \quad=\mathrm{C}=216 \\
& \text { Alkalinity }=\mathrm{D}=282 \\
& \mathrm{pH} \quad=7.1 \\
& \mathrm{pH}_{\mathrm{s}}=(9.3+\mathrm{A}+\mathrm{B})-(\mathrm{C}+\mathrm{D}) \\
& =(9.3+0.1+1.9)-(1.9+2.5) \\
& =11.3-4.4 \\
& =6.9 \\
& \mathrm{I}_{\text {sat }} \quad=\mathrm{pH}-\mathrm{pH}_{\mathrm{s}} \\
& =7.1-6.9 \\
& =+0.2
\end{aligned}
$$

Since it is a plus quantity it indicates the scale forming tendencies of water. Ryznar stability index

$$
\begin{array}{cl}
\mathrm{I}_{\text {stab }} & =2 \mathrm{pH}_{\mathrm{s}}-\mathrm{pH} \\
= & 6.9 \mathrm{X} 2-7.1 \\
= & 13.8-7.1 \\
= & 6.7
\end{array}
$$

Since the value is in between 6 and 7 it will neither scale forming nor corrosive. The very low positive value of +0.2 of Langelier saturation index indicates the border line nature

$$
\begin{aligned}
& \text { Sample 5- bore well }- \text { V.Marudhur } \\
& \begin{aligned}
\text { Total solids } & \mathrm{A} \quad=1200 \\
\text { Temperature } & \mathrm{B} \quad=30^{\circ} \mathrm{C} \\
\text { Calcium hardness } & =\mathrm{C}=689 \\
\text { Alkalinity } & =\mathrm{D}=899 \\
\mathrm{pH} & =7.8 \\
\mathrm{pH} & =(9.3+\mathrm{A}+\mathrm{B})-(\mathrm{C}+\mathrm{D}) \\
& =(9.3+0.2+1.9)-(2.4+3.0) \\
& =11.4-5.4 \\
& =6.0 \\
& =\mathrm{pH}-\mathrm{pH}_{\mathrm{s}}
\end{aligned}
\end{aligned}
$$




$$
\begin{aligned}
& =7.8-6.0 \\
& =+1.8
\end{aligned}
$$

Since it is a plus quantity it indicates the scale forming tendencies of water. Ryznar stability index

$$
\begin{aligned}
\mathrm{I}_{\mathrm{stab}} \quad= & 2 \mathrm{pH}_{\mathrm{s}}-\mathrm{pH} \\
& =6.0 \times 2-7.8 \\
& =12-7.8 \\
& =4.2
\end{aligned}
$$

Since the value is below 6.0 the water will have the tendency to deposit scale.

$$
\begin{aligned}
& \text { Sample 6-stagnated water - collectorate } \\
& \begin{array}{l}
\text { Total solids } \\
\text { Temperature }
\end{array} \quad \mathrm{A} \quad=350 \\
& \text { Calcium hardness } \quad=30^{\circ} \mathrm{C} \\
& \begin{aligned}
\text { Alkalinity } & =\mathrm{C}=112 \\
\mathrm{pH} & =7.3 \\
\mathrm{pH} & =(9.3+\mathrm{A}+\mathrm{B})-(\mathrm{C}+\mathrm{D}) \\
& =(9.3+0.1+1.9)-(1.7+2.0) \\
& =11.3-3.7 \\
& =7.6 \\
& =\mathrm{pH}-\mathrm{pH}_{\mathrm{s}} \\
& =7.3-7.6 \\
& =-0.3
\end{aligned}
\end{aligned}
$$

Since it is a negative quantity it indicates the corrosive tendency of water.

Ryznar stability index

$$
\begin{aligned}
\mathrm{I}_{\text {stab }} \quad= & 2 \mathrm{pH}_{\mathrm{s}}-\mathrm{pH} \\
& =7.6 \times 2-7.3 \\
& =15.2-7.3 \\
& =7.9
\end{aligned}
$$

Since the value is above 7.0 the water will be corrosive.

\section{Sample 7 - rain water}

$$
\begin{aligned}
& \text { Total solids }=\mathrm{A}=320 \\
& \text { Temperature }=\mathrm{B}=30^{\circ} \mathrm{C} \\
& \text { Calcium hardness } \quad=\mathrm{C}=183 \\
& \text { Alkalinity }=\mathrm{D}=239 \\
& \mathrm{pH} \quad=7.1 \\
& \mathrm{pH}_{\mathrm{s}}=(9.3+\mathrm{A}+\mathrm{B})-(\mathrm{C}+\mathrm{D}) \\
& =(9.3+0.1+1.9)-(1.9+2.4) \\
& =11.3-4.3 \\
& =7.0 \\
& \mathrm{I}_{\text {sat }} \quad=\mathrm{pH}-\mathrm{pH}_{\mathrm{s}} \\
& =7.1-7.0 \\
& =+0.1
\end{aligned}
$$

Since it is a positive quantity it indicates the scale forming tendency of water. Ryznar stability index 


$$
\begin{aligned}
\mathrm{I}_{\text {stab }} \quad= & 2 \mathrm{pH}_{\mathrm{s}}-\mathrm{pH} \\
& =7.0 \times 2-7.1 \\
& =14.0-7.1 \\
& =6.9
\end{aligned}
$$

Since the value is between 6 and 7 the water will be neither corrosive nor scale forming. The very low positive value of Langelier saturation index indicates the border line nature.

Table 4. Percetage removal of $\mathrm{Ca}^{2+}$.

\begin{tabular}{|c|c|c|c|c|c|c|}
\hline \multirow{2}{*}{ Sample No } & \multirow{2}{*}{$\begin{array}{c}\text { Concentration } \\
\text { In ppm }\end{array}$} & \multicolumn{5}{|c|}{ Stirring time } \\
\cline { 2 - 7 } & 1437 & 16 & 34 & 49 & 51 & 53 \\
\hline 1 & 996 & 20 & 40 & 58 & 60 & 63 \\
\hline 2 & 1810 & 14 & 30 & 43 & 47 & 50 \\
\hline 3 & 842 & 22 & 45 & 65 & 75 & 80 \\
\hline 5 & & & & & & \\
\hline
\end{tabular}

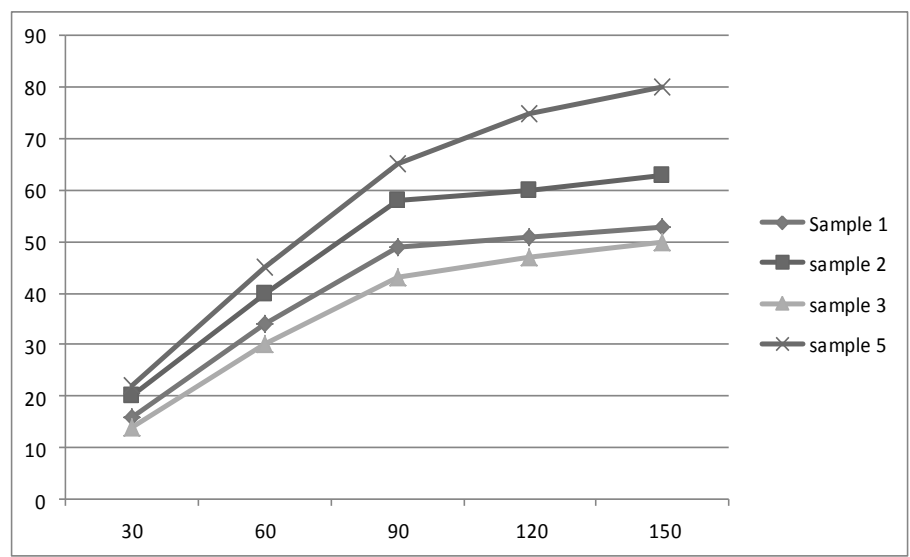

Figure 1. Effect of time on removal of $\mathrm{Ca}^{2+}$.

The adsorption of calcium and magnesium by batch process from the water samples (1, 2, 3 and 5) were made. These samples were chosen because they were found to contain comparatively large amount of hardness. Therefore they were subjected to CNSL resin treatment in order to check its efficiency to remove hardness of water. $100 \mathrm{ml}$ of each sample is mixed with known amount of CNSL resin and stirred in a magnetic stirrer with temperature control. After known interval of time the solution was filtered and amount of calcium and magnesium were estimated by EDTA method. The following tables show the absorption of cation under various conditions. Magnesium was calculated as the difference between total hardness and calcium hardness. 
Table 4. Percetage removal of $\mathrm{Mg}^{2+}$.

\begin{tabular}{|c|c|c|c|c|c|c|}
\hline \multirow{2}{*}{ Sample No } & Concentration & \multicolumn{5}{|c|}{ Stirring time } \\
\cline { 3 - 7 } & In ppm & $30 \min$ & $60 \min$ & $90 \min$ & $120 \min$ & $150 \min$ \\
\hline 1 & 319 & 14 & 29 & 40 & 53 & 56 \\
\hline 2 & 666 & 10 & 19 & 36 & 43 & 46 \\
\hline 3 & 402 & 11 & 21 & 39 & 51 & 52 \\
\hline 5 & 153 & 16 & 34 & 43 & 58 & 62 \\
\hline
\end{tabular}

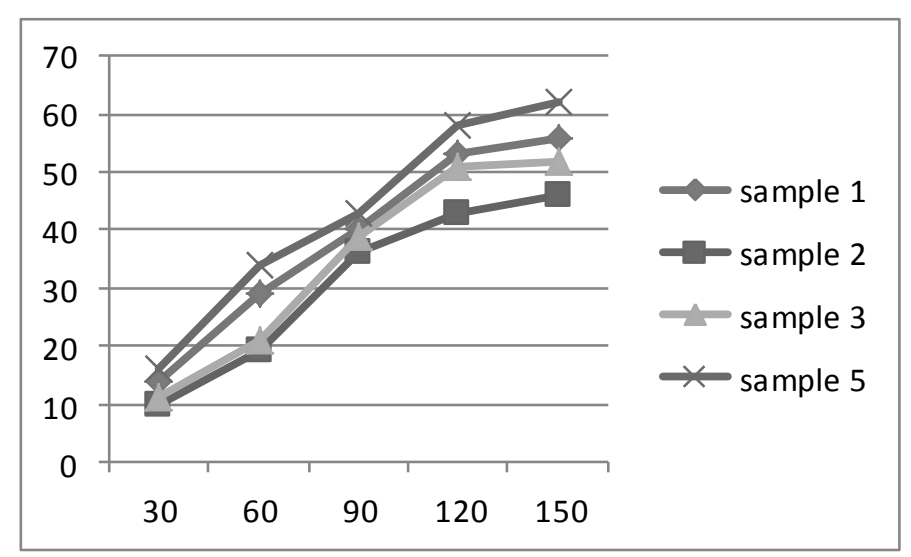

Figure 2. Effect of time on removal of $\mathrm{Mg}^{2+}$.

\section{CONCLUSION}

The above fiqure 1 indicate the percentage removal of calcium ions by CNSL resin upon treatment by varying stirring time. These results clearly shows that the percentage of removal of calcium increases when stirring time increases. The order of removal of calcium among samples is:

\section{Sample $5>$ sample $2>$ sample $1>$ sample 3}

The above fiqure 2 indicate the percentage removal of Magnesium ions by CNSL resin upon treatment by varying stirring time. These results clearly shows that the percentage of removal of Magnesium increases when stirring time increases. The order of removal of calcium among samples is:

\section{Sample $5>$ sample $2>$ sample $1>$ sample 3}

The percentage removal of calcium in all these cases was found to be higher than magnesium at identical conditions and it can be explained by the hydrated ionic size relationship. Since the $\mathrm{Ca}^{2+}$ ion is bigger ion compared to $\mathrm{Mg}^{2+}$ it gets less hydrated therefore hydrated ionic size of $\mathrm{Ca}^{2+}$ is less compared to $\mathrm{Mg}^{2+}$. Therefore it gets easily enter in the pores of resin and therefore it is comparatively removed as larger quantities. 


\section{Acknowledgement}

It is my pleasure to acknowledge my debt to the almighty God for giving me strength and thank my guide Dr. G. Bhoopathy (A. A. G. Arts College, Villupuram) for his guidance throughout my research. It is also my bounden duty to express my sense of gratitude to the intimates directly involved directly or indirectly, in bringing out this paper.

\section{References}

[1] Jayarama Reddy, P., A text book of Hydrology, Laxmi publications (pvt) Ltd., New Delhi 1996.

[2] Physio - chemical examination of water sewage and industrial effluents - by N.Manivasagam, Coimbatore -18.

[3] www.cashewindustries_udipi pages.com 